\title{
Reengineering Cracker-Dryer Machine Based on Fan speed and Temperature Considering Drying Time, Final Weight and Energy Consumption Factor
}

\author{
Emon Rifai ${ }^{a}$, Sabarudin Ahmad ${ }^{b}$, Anis Arendra ${ }^{c}$, Rifky Maulana Yusron ${ }^{c}$ \\ ${ }^{a}$ Department of Industrial Engineering ,Bahaudin Mudhary University, Sumenep, Indonesia \\ ${ }^{b}$ Department of Industrial Engineering, University of Trunojoyo Madura,Bangkalan, Indonesia \\ ${ }^{c}$ Department of Mechanical Engineering, University of Trunojoyo Madura,Bangkalan, Indonesia
}

\begin{abstract}
A B S T R AC T
Redesign and building a cracker drying machine should give priority to several factors to find the optimal point, one of which is by conducting experimental experiments. This research was carried out to find out from the tool and also pay attention to several things, such as temperature and fan speed. If one of these factors is ignored, it will not produce dry crackers and the dried crackers are less than optimal. The Independent parameters used in this research are temperature and fan speed. Dependent parameters used in this research are concerning drying time, final weight, and energy consumption. Design experiment using Factorial 3x3. Fan speed has 3 levels, they are 1000rpm, 1500rpm and 2000rpm. The Temperature parameter has 3 levels, they are 16,19 , and $21^{\circ} \mathrm{C}$. Based on the design of experiment results, it was found that the drying time response for the combination that has the highest ranking is at a temperature of $19^{\circ} \mathrm{C}$ with a 2000rpm fan speed resulting in a drying time of 182,677 minutes.
\end{abstract}

Keywords: Cracker, Dryer Machine, Fan speed, Temperature.

Article History

Received 01 November 21

Received in revised form 21 November 21

Accepted 14 December 21

\section{Introduction}

Madura is an island with a climate that tends to be dry, this has a great influence on cracker entrepreneurs on the island because the sun always shines throughout February to September [1]. Outside this month, it is the rainy season. The current climate change is a major problem in the cracker drying system. The irregularity of rainfall makes it difficult to determine the drying time of cracker. The loss experienced by entrepreneurs is the delay in drying so that the fulfillment of needs is not optimally fulfilled. Although the manual cracker drying system is not a standard or rigid system, a means is needed to take into account the opportunities for inaccurate rainfall so that it becomes a new analysis for determining the start of the rainy season, besides that the chances of delays in drying can be reduced. The center for the fish cracker processing industry in Madura has been going on for a long time, which is located in the Bangkalan Regency which is one of the centers for making fish crackers. One way to take advantage of these marine fish is to make fish crackers[2][3].

Energy is quite important in supporting human life so that the progress of human civilization is influenced by energy and its consumption [4]. Efficiency and optimization of the level of energy use in industries are urgent[5]. As a result, it is suggested that there are several methods to improve process performance and optimize the energy required. New technologies such as those using renewable energy can be widely used in the context of protecting the environment and reducing greenhouse gas emissions[6][7]

The purpose of this study was to determine the effect of temperature, humidity, and air pressure on the drying machine on the drying rate in the design of a drying machine for drying crackers.

\section{Literature Review}

Drying is the process of removing the water content from the material until it reaches the lowest water content or as desired, with the hope that the development of microorganisms and enzymes that can cause spoilage is inhibited or stopped altogether so that the material can be stored longer. The common way that many cracker makers do is dry the crackers directly in the sun. This method of drying is very dependent on weather conditions, it takes quite a long time if the weather is unpredictable.

There are several ways that can be done to overcome this, namely by using a dryer. The dryer can be used at any time, regardless of weather conditions, so that in the rainy season it can still be used without spending

\footnotetext{
* Corresponding author.

E-mail address: emonridai@unibamadura.ac.id.
} 
a lot of money. This cracker dryer is quite simple, the manufacturing process and its work can be done by anyone because it is not complicated.

Some of the fish crackers circulating in the community contain carbohydrates and high oil absorption. Nutrient addition of crackers can be done by adding fish stick[8]s. The business of making fish or shrimp crackers is generally on a small scale because the process of making fish crackers does not require large capital. However, if this business is developed, it will become a medium-sized business and even a large business. Public interest in fish crackers is also quite high, marked by the high demand for fish crackers in the regions, so the market potential for this cracker business is still very large to be developed[9].

\section{Methods}

The main frame of this cracker dryer is made of $2 \times 4$ and $4 \times 4$ hollow iron. plywood with a thickness of $12 \mathrm{~mm}$ is used as the wall of the dryer, making it possible to isolate the air inside the dryer system from the air outside. air conditioner and blower are used to regulate the temperature in the dryer. Cracker dryer machine is shown in figure 1. The study was conducted for four months. Starting from the construction of the drying machine, followed by data collection, the final stage of this research is the analysis of the data obtained during the research including the final weight of the crackers, the energy consumed during the drying process and the drying time during the cracker drying process.

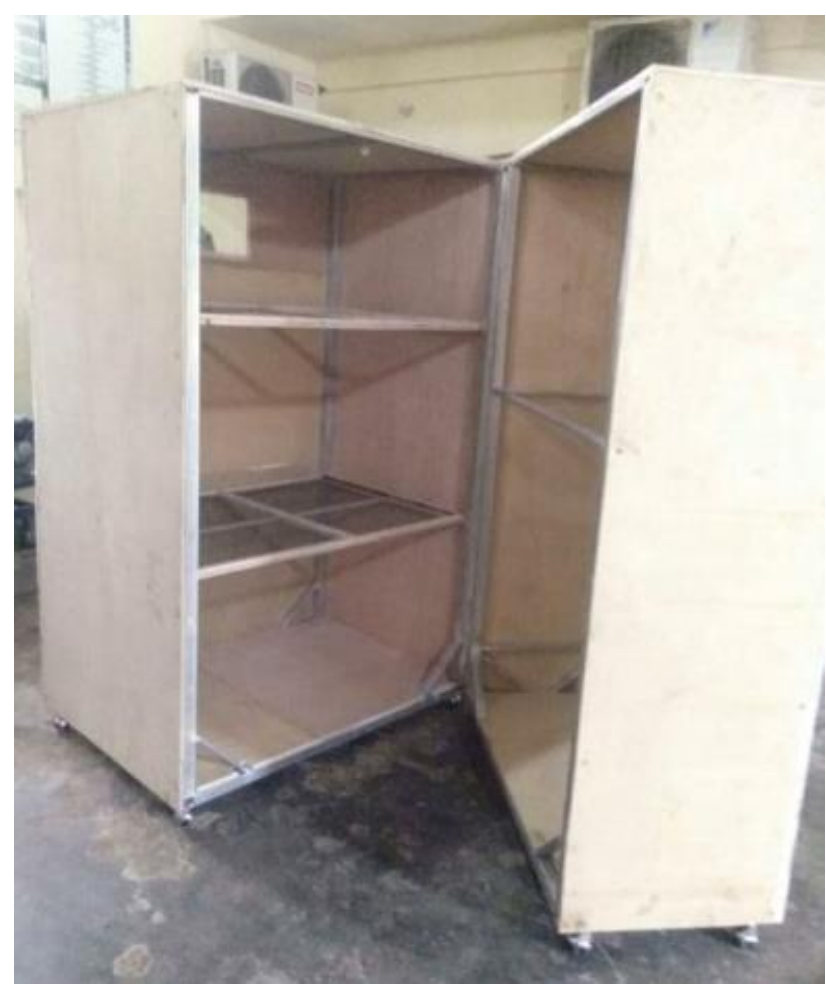

Figure 1. Cracker dryer machine

\subsection{Variable}

The Independent parameters used in this research are temperature and fan speed. Dependent parameters used in this research are concerning drying time, final weight, and energy consumption. Design experiment using Factorial 3x3. Fan speed has 3 levels, they are 1000rpm, $1500 \mathrm{rpm}$ and 2000rpm. The Temperature parameter has 3 levels, they are $16^{\circ} \mathrm{C}, 19^{\circ} \mathrm{C}$, and $21^{\circ} \mathrm{C}$. each cracker measured their weight before and after treatment. To find out how much weight is lost during the drying process. measuring using a digital scale. Initial weight of every cracker is 750 gr. Energy consumption on each parameter monitored using Arduino Uno ATmega28 Each parameter has 3 replications shown on table 1.

Table 1. Research Mathods.

\begin{tabular}{|c|c|c|c|c|c|}
\hline \multirow{2}{*}{ Fan Speed } & \multicolumn{3}{|c|}{ Temperature $\left({ }^{\circ} \mathrm{C}\right)$} & \multirow{2}{*}{$\begin{array}{c}\text { Final } \\
\text { weight }\end{array}$} & \multirow{2}{*}{$\begin{array}{c}\text { Energy } \\
\text { Consumption }\end{array}$} \\
\hline & 16 & 19 & 21 & & \\
\hline $1000 \mathrm{rpm}$ & $\mathrm{X} 111$ & $\mathrm{X} 211$ & $\mathrm{X} 311$ & & \\
\hline $1000 \mathrm{rpm}$ & $\mathrm{X} 112$ & $\mathrm{X} 212$ & $\mathrm{X} 312$ & & \\
\hline $1000 \mathrm{rpm}$ & $\mathrm{X} 113$ & X213 & X313 & & \\
\hline $1500 \mathrm{rpm}$ & $\mathrm{X} 121$ & $\mathrm{X} 221$ & X321 & & \\
\hline $1500 \mathrm{rpm}$ & $\mathrm{X} 122$ & $\mathrm{X} 222$ & X322 & & \\
\hline $1500 \mathrm{rpm}$ & $\mathrm{X} 123$ & $\mathrm{X} 223$ & X323 & & \\
\hline $2000 \mathrm{rpm}$ & $\mathrm{X} 131$ & $\mathrm{X} 231$ & X331 & & \\
\hline $2000 \mathrm{rpm}$ & $\mathrm{X} 132$ & $\mathrm{X} 232$ & X332 & & \\
\hline $2000 \mathrm{rpm}$ & X133 & $\mathrm{X} 233$ & X333 & & \\
\hline
\end{tabular}

In this research we had check sheet used to record the results of the data studied or taken at the time of the study. The data taken later includes the independent variable and the dependent variable. Below is a hypothesis of the influence of factors on time drying:

1. Effect of fan speed factor (a) on drying time

$\mathrm{H} 0$ : There is no influence of fan speed factor on drying time.

$\mathrm{H} 1$ : There is an effect of fan speed factor on drying time.

2. Effect of temperature factor (b) on drying timel

$\mathrm{H} 0$ : There is no effect of temperature factor on time drying.

$\mathrm{H} 1$ : There is an effect of temperature factor on drying time.

3. The interaction effect of factor A (fan speed), factor B (temperature) on drying time

$\mathrm{H} 0$ : There is no effect of temperature factor on drying time.

$\mathrm{H} 1$ : There is an effect of temperature factor on drying time.

4. Decision-making

If the calculated $\mathrm{F}$ value $>\mathrm{F}$ table then reject $\mathrm{H} 0$

If the calculated $\mathrm{F}$ value $<\mathrm{F}$ table then accept $\mathrm{H} 0$

Or

If the P-value 0.05 then reject $\mathrm{H} 0$

If the P-value 0.05 then accept $\mathrm{H} 0$ 


\section{Result}

Research result shown on table 2. Based on table 2 highest consumption energy found on $1500 \mathrm{rpm}$.

Table 2. Research result

\begin{tabular}{|c|c|c|c|c|}
\hline Fan speed & Temp & $\begin{array}{c}\text { Drying } \\
\text { Time }\end{array}$ & $\begin{array}{c}\text { Final } \\
\text { Weight }\end{array}$ & $\begin{array}{c}\text { Energy } \\
\text { Consummption }\end{array}$ \\
\hline $1000 \mathrm{rpm}$ & 16 & 246 & 375 & 3,55 \\
\hline $1000 \mathrm{rpm}$ & 16 & 232 & 375 & 4,80 \\
\hline $1000 \mathrm{rpm}$ & 16 & 242 & 375 & 4,47 \\
\hline $1000 \mathrm{rpm}$ & 19 & 158 & 385 & 3,19 \\
\hline $1000 \mathrm{rpm}$ & 19 & 200 & 365 & 3,95 \\
\hline $1000 \mathrm{rpm}$ & 19 & 190 & 370 & 3,80 \\
\hline $1000 \mathrm{rpm}$ & 21 & 200 & 350 & 4,61 \\
\hline $1000 \mathrm{rpm}$ & 21 & 224 & 355 & 4,65 \\
\hline $1000 \mathrm{rpm}$ & 21 & 229 & 380 & 4,58 \\
\hline $1500 \mathrm{rpm}$ & 16 & 225 & 375 & 4,23 \\
\hline $1500 \mathrm{rpm}$ & 16 & 217 & 380 & 4,75 \\
\hline $1500 \mathrm{rpm}$ & 16 & 228 & 365 & 5,02 \\
\hline $1500 \mathrm{rpm}$ & 19 & 230 & 365 & 4,62 \\
\hline $1500 \mathrm{rpm}$ & 19 & 238 & 385 & 5,03 \\
\hline $1500 \mathrm{rpm}$ & 19 & 241 & 370 & 4,80 \\
\hline $1500 \mathrm{rpm}$ & 21 & 200 & 350 & 4,61 \\
\hline $1500 \mathrm{rpm}$ & 21 & 224 & 355 & 4,65 \\
\hline $1500 \mathrm{rpm}$ & 21 & 229 & 380 & 4,58 \\
\hline $2000 \mathrm{rpm}$ & 16 & 220 & 380 & 3,90 \\
\hline $2000 \mathrm{rpm}$ & 16 & 225 & 365 & 4,46 \\
\hline $2000 \mathrm{rpm}$ & 16 & 222 & 385 & 4,82 \\
\hline $2000 \mathrm{rpm}$ & 19 & 214 & 350 & 4,33 \\
\hline $2000 \mathrm{rpm}$ & 19 & 231 & 355 & 4,69 \\
\hline $2000 \mathrm{rpm}$ & 19 & 230 & 380 & 4,69 \\
\hline $2000 \mathrm{rpm}$ & 21 & 187 & 365 & 3,30 \\
\hline $2000 \mathrm{rpm}$ & 21 & 204 & 275 & 2,75 \\
\hline $2000 \mathrm{rpm}$ & 21 & 200 & 360 & 2,74 \\
\hline
\end{tabular}

\section{Discussions}

\subsection{Interaction Analysis Effect of drying time}

The following below is a graph of the main effect plot of drying time of the temperature and fan speed factors to the duration of drying time. Figure of Interaction analysis effect of drying gas shown on Figure 2.

1. In the temperature factor, there are 3 levels, namely $16 \mathrm{C}, 19 \mathrm{C}$, and $21 \mathrm{C}$. at the first level, which is $16 \mathrm{C}$, the average drying time is $>225$ minutes, at the second level, namely $19 \mathrm{C}$, the average drying time is 214 minutes, while at the third level, the average drying time is $21^{\circ} \mathrm{C}$. drying 205 minutes.

2. The fan speed factor has 3 levels, namely $2000 \mathrm{rpm}, 1500 \mathrm{rpm}$ and $1000 \mathrm{rpm}$. At the $2000 \mathrm{rpm}$ level, the average drying time is 213 minutes, the $1500 \mathrm{rpm}$ level requires a drying time of 220 minutes, while the $1000 \mathrm{rpm}$ level requires a drying time of 215 minutes.

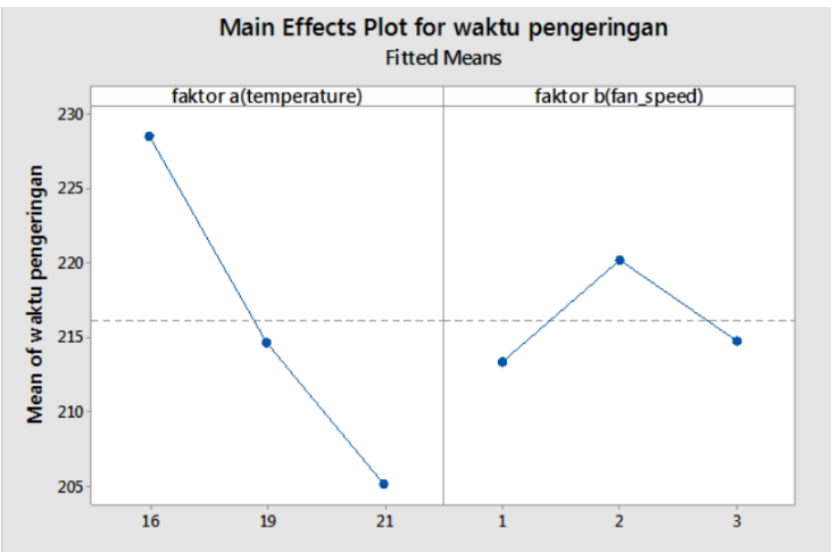

Figure 2. Main Plot drying machine

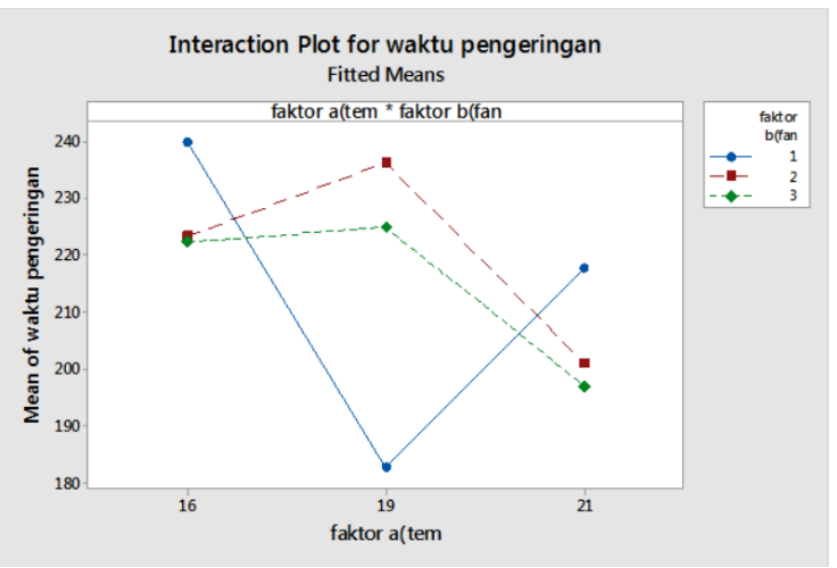

Figure 3. Interaction Plot drying time and temerature

From Figure 3, it can be explained that the temperature factor and the fan speed factor have interactions and the gradient lines intersect each other, which means that the two factors are mutually dependent.

1. Temperature factor

P-value $0.004<0.05$ so reject $\mathrm{H} 0$, there is no significant effect of temperature on drying time.

2. Fan speed factor

P-value 0,505 > 0,05 so accept H1, there is a significant effect of fan speed on drying time.

3. Combination of temperature factor and fan speed

P-value $0.000<0.05$ so reject $\mathrm{H} 0$, there is no significant effect of temperature and fan speed on drying time 


\subsection{Final weight effect interaction analysis}

1. In factor temperature there are $316 \mathrm{C}, 19 \mathrm{C}$, and $21 \mathrm{C}$. at the first level, which is $16 \mathrm{C}$, the average final weight is 375 grams per minute, at the second level, which is $19 \mathrm{C}$, the average final weight is 369 grams. at the third level which is $21 \mathrm{C}$ the average final weight is 366.5 grams.

2. Factor $b$ is fan speed. At the level of $2000 \mathrm{rpm}$ has an average final weight of 370 grams, for the level of $1500 \mathrm{rpm}$ with requires a final weight of 373 grams, while for the third level $1000 \mathrm{rpm}$ requires a final weight of 368 grams.

\subsection{ANOVA Test}

1. Temperature factor

The P-value is $0.019<0.05$, so reject H0, there is no significant effect of temperature on energy consumption.

2. Fan speed factor

P-value $0.034<0.05$ so reject H0, there is no significant effect of temperature on drying time.

3. Combination of temperature factor and fan speed

The P-value is $0.001<0.05$, so reject $\mathrm{H} 0$, there is no significant effect of temperature and fan speed on energy consumption.

The results of this research are similar to some research [10], [11]

\section{Conclusions}

The cracker drying machine on this research is designed for the homescale fish cracker industry, this machine has a drying capacity of $7.5 \mathrm{~kg}$ to be dried which is used to dry the crackers. From the experimental results obtained for the drying time response after the drying process, it was found that the drying time response variable had a P-value of $0.000<0.05$ so that by rejecting $\mathrm{H} 0$, there was no significant effect of temperature and fan speed on time.

drying. In addition, it was obtained for the response to drying time after the drying process, it was found that the final weight response variable had a P-value of $0.547>0.05$ so that receiving $\mathrm{H} 1$, there was a significant effect of temperature on the final weight. The results for the drying time response after the drying process were found that the energy consumption response variable had a P-value of $0.001<0.05$ so that by rejecting $\mathrm{H} 0$, there was no significant effect of temperature and fan speed on energy consumption.

In the comparison test, the response of drying time and final weight interacted with the temperature factor and fan speed. The best comparative test was obtained from the response of drying time with a temperature of 19C and high fan speed (1) which was 182,557 minutes, while the final weight response with a temperature of $21 \mathrm{C}$ and high heating time (1) was 361,667.

\section{REFERENCES}

[1] N. M. Hidayat, A. E. Pandiangan, and A. Pratiwi, "Identifikasi Perubahan Curah Hujan Dan Suhu Udara Menggunakan Rclimdex Di Wilayah Serang," J. Meteorol. Klimatologi dan Geofis., vol. 5, no. 2, pp. 37-44, 2019, doi: 10.36754/jmkg.v5i2.57.

[2] M. M. Sianita, N. Purwidiani, S. C. Wibawa, and N. Kusumawati, “Analisis Masa Simpan dan Kandungan Gizi Produk Kerupuk Ikan ' Sholawat Ummi' Analysis of Shelf Life and Nutritional Content of Fish Crackers 'Sholawat Ummi ,"' pp. 268-274, 2020.

[3] A. Zulfahmi, F. Swastawati, and R. Romadhon, "Pemanfaatan Dagingikan Tenggiri (Scomberomorus Commersoni) Dengan Konsentrasi Yang Berbedapada Pembuatan Kerupuk Ikan," J. Pengolah. dan Bioteknol. Has. Perikan., vol. 3, no. 4, pp. 133139, 2014.

[4] I. G. A. K. R. Handayani, E. As’Adi, G. Hamzah, T. Leonard, and G. Gunarto, "Relationship between energy consumption in international market and Indonesia prices regulation," Int. J. Energy Econ. Policy, vol. 7, no. 5, pp. 9-15, 2017.

[5] S. P. Türkoğlu and P. S. Ö. Kardoğan, "The role and importance of energy efficiency for sustainable development of the countries," Lect. Notes Civ. Eng., vol. 7, no. January, pp. 53-60, 2018, doi: 10.1007/978-3-319-64349-6_5.

[6] A. Jambor, "Determinants of CO 2 Emission : A Global Evidence," no. November, 2018.

[7] S. Saint Akadiri, F. V. Bekun, E. Taheri, and A. C. Akadiri, "Carbon emissions, energy consumption and economic growth: A causality evidence," Int. J. Energy Technol. Policy, vol. 15, no. 2-3, pp. 320-336, 2019, doi: 10.1504/ijetp.2019.10019648.

[8] B. G. Chudasama, S. M. Zofair, D. V Bhola, and T. H. Dave, "Development and characterization of fish crackers prepared from the bull's eye (Priacanthus hamrur, Forsskal, 1775) fish meat and different starches," J. Entomol. Zool. Stud., vol. 7, no. 3, pp. 401-406, 2019.

[9] W. Zzaman, M. M. Yusoff, and T. A. Yang, "Preparation and properties of fish cracker from different freshwater fish species," Int. Food Res. J., vol. 24, no. 5, pp. 1858-1862, 2017.

[10] S. Salisu, O. O. Joel, and A. O. Murray, "Design, Construction, and Simulation of a Solar Fish Dryer," Int. J. Trend Sci. Res. Dev., vol. Volume-3, no. Issue-2, pp. 239-244, 2019, doi: 10.31142/ijtsrd20299.

[11] C. a Komolafe, C. R. Engr, I. O. Ogunleye, D. Ph, and a O. D. Adejumo, "Design and Fabrication of a Convective Fish Dryer .," Pacific J. Sci. Technol., vol. 12, no. 1, pp. 89-97, 2011. 